\title{
Advertising Spending, Firm Performance, and the Moderating Impact of CSR
}

Assaf, A. George; Josiassen, Alexander; Ahn, Jin Sun; Mattila, Anna S.

\author{
Document Version \\ Accepted author manuscript \\ Published in: \\ Tourism Economics \\ DOI: \\ $10.1177 / 1354816617704739$ \\ Publication date: \\ 2017 \\ License \\ Unspecified
}

Citation for published version (APA):

Assaf, A. G., Josiassen, A., Ahn, J. S., \& Mattila, A. S. (2017). Advertising Spending, Firm Performance, and the Moderating Impact of CSR. Tourism Economics, 23(7), 1484-1495. https://doi.org/10.1177/1354816617704739

Link to publication in CBS Research Portal

\section{General rights}

Copyright and moral rights for the publications made accessible in the public portal are retained by the authors and/or other copyright owners and it is a condition of accessing publications that users recognise and abide by the legal requirements associated with these rights.

\section{Take down policy}

If you believe that this document breaches copyright please contact us (research.lib@cbs.dk) providing details, and we will remove access to the work immediately and investigate your claim.

Download date: 26. Apr. 2023

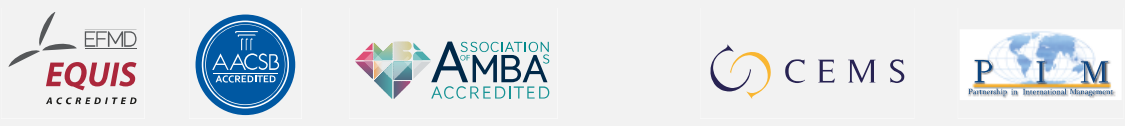




\title{
Advertising Spending, Firm Performance, and the Moderating Impact of CSR
}

\section{A. George Assaf, Alexander Josiassen, Jin Sun Ahn, and Anna S. Mattila}

\author{
Journal article (Accepted manuscript*)
}

\section{Please cite this article as:}

A. G., Josiassen, A., Ahn, J. S., \& Mattila, A. S. (2017). Advertising Spending, Firm Performance, and the Moderating Impact of CSR. Tourism Economics, 23(7), 1484-1495. D0I: 10.1177/1354816617704739

\section{DOl: https://doi.org/10.1177/1354816617704739}

Copyright (ㅇ The Author(s) २017. Reprinted by permission of SAGE Publications.

* This version of the article has been accepted for publication and undergone full peer review but has not been through the copyediting, typesetting, pagination and proofreading process, which may lead to differences between this version and the publisher's final version AKA Version of Record.

Uploaded to CBS Research Portal: February २०19 


\title{
Advertising Spending, Firm Performance and the Moderating Impact of CSR
}

\begin{abstract}
This paper investigates the potential of corporate social responsibility (CSR) to influence the link between advertising spending and firm performance. Drawing upon the literature of corporate social responsibility (CSR) we hypothesize that CSR positively moderates the relationship between advertising spending and firm performance. We focus on two types of firm performance: Sales and firm value. Using two samples from both the hotel and restaurant industries, we found that firms with higher levels of CSR enjoy higher returns on advertising spending than firms with lower levels of CSR. We discuss the theoretical and managerial implications of these findings and provide direction for future research.
\end{abstract}

\section{Introduction}

The past decade has seen an increasing need amongst managers and investors to examine the factors that interact with advertising in the impact on firm performance (Luo and de Jong, 2012). Recent studies in marketing have described "testing the value and accountability of advertising spending as a major research priority in marketing" (Luo and de Jong, 2012, p605). There is an increasing need to better understand the marketing-finance interface on the hospitality industry (Park and Kang, 2014; Leon and Arana, 2014; Mitrokostas and Apostolakis, 2013). The restaurant industry in the US spent over 1.55 billion in advertising in in the third quarter in 2015 while the corresponding figure was 1.2 billion for travel and tourism (Statista.com). Given such huge expenditures, hospitality companies are under increasing pressure to demonstrate how to make advertising spending more effective. While substantial research has demonstrated that advertising positively affects brand equity (Aaker 1996; Keller 1998; Frieder and Subrahmanyam 2005), customer equity (Keller, 1998), consumer loyalty (Ali Shah and Akbar, 2008), product differentiation (Kirmani and Zeithaml, 1993), and increased price premiums (Ailawadi, Neslin, and Lehmann, 2003), the bar is higher when it comes to demonstrating an effect on firm performance.

Importantly, previous studies testing the relationship between advertising and firm performance are unable to reconcile the mixed findings (Josh and Hanssens, 2009; Han and Manry, 2004; Erickson and Jacobson, 1992). As emphasized by Luo and de Jong (2012), there is a need for a con- 
tingency approach. The link between advertising spending and firm performance is not simple, and assuming that there are no variables interacting with this relationship is unrealistic (Assaf et al., 2015). Yet, research on potential moderators is scant. In this paper, we propose that corporate social responsibility (CSR) might be a key factor in understanding the impact of advertising spending on firm performance. Recent research suggests that firms can thrive as a business by being socially responsible (Eichholtz, Kok, and Quigley, 2010). Previous research in hospitality has investigated the impact of CSR on firm value highlighting the importance of CSR awareness (Rhou, SIngal and Koh, 2016) and appropriate choice of CSR activities (Kang, Lee and Huh, 2010).

There is some evidence to suggest that poor CSR engagement may make advertising less effective (Luo and Bhattacharya, 2006). We argue that higher levels of CSR initiatives enhance consumers' attitude toward the firm and customer satisfaction. Overall, such effects should improve the firm's reputation and make it less costly for the firm to attract and retain customers. Specifically, we address the following research question: Is it efficient to focus on increasing CSR initiatives prior to investing in advertising? Often firms commit millions of dollars to advertising without first assuring a strong CSR foundation. Sometimes a weak CSR reputation may even be the motivation to spend more on advertising. The positive impact of CSR is not only limited to customers. Previous literature shows that positive CSR associations can also enhance investors' attitudes toward the firm (Luo and Bhattacharya, 2006; Kim, Kim and Mattila, 2016).

The present study offers two important contributions to the hospitality literature on advertising spending and firm performance. First, we test whether CSR moderates the advertising spendingfirm performance relationship. We suggest that it is indeed important to account for this variable in order to provide a comprehensive assessment of the relationship between advertising spending and firm performance. Joshi and Hanssen (2010) recently investigated the role of profit and sales in the impact of advertising on firm performance. Luo and de Jong (2012) tested the mediating role of stock analysts' recommendations on the advertising spending - firm value relationship. Here, we extend such findings by examining the moderating impact of CSR.

Second, we test our hypotheses with two segments of the hospitality industry: restaurants and hotels. Advertising spending in the service industry tends to be nearly twice as high as in the manufacturing sector (Chauvin and Hirschey, 1993; Ho, Keh and Ong, 2005). Further, as spend- 
ing on advertising in these two industries continues to rise (Assaf et al., 2015; Hsu and Jang, 2008), they present an interesting context in which to test our hypotheses. By focusing on these two industries, we also present an important contribution to the advertising literature, as studies testing the advertising-firm performance relationship in the hospitality industry are limited.

The rest of the paper is organized as followed. First, we present our theoretical framework and hypotheses. Then, we discuss the sample and data characteristics. Finally, we present the results and discuss the implications of the study.

\section{Moderating Impact of CSR}

We address the moderating impact of CSR on advertising spending within the context of two performance indicators: sales and firm value. The former is more related to consumer sentiments, while the latter is more linked to investor attitudes. Although the effect of advertising on sales is well established (Assaf et al., 2015; Chen and Lin, 2013; O’Neill et al., 2008; Hanssens, Parsons, and Schultz, 2001; Abdel-Khalik, 1975; Peles, 1970), the focus on firm value is more recent. As indicated by Joshi and Hanssens (2010, p20) a "business should be run to maximize the return on shareholders' investment, and shareholder value analysis is fast becoming a new standard for judging managerial action".

The impact of advertising spending on consumers' and investors' decision-making processes mainly manifests via two mechanisms: the signaling effect and the spillover effect. According to the signaling theory, advertising spending can act as a signal to consumers and investors that the product quality is high and the risks are low (Joshi and Hanssens, 2009). It is also a reflection on the overall financial well-being and future earnings of the firm. Even when a firm is performing well on several dimensions (e.g. R\&D; expansion; new projects), advertising is needed to signal the strong performance to various stakeholders. As highlighted by Luo and de Jong (2012), consumers and investors are more receptive to firms with high brand visibility induced by advertising (Joshi and Hanssens, 2009; Pauwels et al., 2004; Mizik and Jacobson, 2003; Boyd and Schonfeld, 1977).

Advertising can also help a firm to differentiate itself from its competitors. While such "equity is 
ostensibly directed at customers and prospects, it can spill over into investment behavior as well" (Joshi and Hanssens, 2010, p22). As highlighted by Aaker (1996), advertising creates strong brand associations with consumers and investors. It also influences customer attitudes and perceptions, creating higher consumer loyalty and satisfaction (Rust et al., 2004), thus enabling firms to charge higher prices (Farquhar, 1989; Mela, Gupta, And Lehmann, 1997) and to attain greater market share (Boulding, Lee, and Staelin, 1994). Decision theory also supports the spillover effect of advertising (Heath and Tversky, 1991). Advertising leads to higher levels of familiarity and lower levels of uncertainty, thus having a positive impact on both consumers and investors (Joshi and Hanssens, 2009; Luo and de Jong, 2012).

However, there is some controversy in the literature about whether advertising really affects firm performance. Several recent studies, for instance, rejected the hypothesis that advertising spending results in higher sales or higher firm value (e.g. Ali Shah et al., 2008). This inconsistency exists because previous studies failed to consider some underlying factors that affect the advertising spending - firm value link (Luo and de Jong, 2012). To that end, we examine the moderating impact of CSR.

As the society puts increasing emphasis on CSR, firms are expected to act not only in their own interest, but to benefit, or at least not burden, the society as a whole (Vanhamme et al., 2012). Consumers and consumer-advocate groups show an increasing interest in the morality of firms' actions. In a recent study, $91 \%$ of consumers stated that they wanted to know about the corporate social responsibility status and progress of firms they consider dealing with (Schwartz, 2015). Similarly, a recent report (PWC, 2012) reveals that investors are increasingly using CSR information in their investment strategies. CSR can be a source of competitive advantage, thus influencing shareholders' perceptions of the firm (Hull and Rothenberg 2001). In sum, there is converging evidence to suggest that companies do well by doing good (e.g., Kang, Germann and Grewal, 2016).

Often firms that engage in CSR are interested in its effects on the advertising spending - firm performance relationship (Luo and Du, 2015). When McDonalds in 2014 launched its "Our food, your questions" campaign, the explicit purpose was to enhance transparency of their CSR initiatives and to empower customers. Nonetheless the question is whether McDonalds is merely communicating good deeds, or is it possible that such CSR initiatives could facilitate a higher 
effect of advertising spending?

In order to answer such questions, it is critical to consider the interaction of CSR with the advertising spending - firm performance relationship. On one hand, some previous research suggests that CSR endeavors are simply a cost to firms. The 'economic argument' posits that firms should not allocate resources to CSR because it would be inefficient use of resources, and thus result in an alternative cost. This argument draws on the notions of Milton Friedman (Friedman, 2013) and suggests that firms must focus on what they are good at and serve their own self-interest. The self-interest of millions of firms and consumers will result in an optimal allocation of resources, and therefore, in the highest possible wealth for society. The economic argument further suggests that the few aspects which cannot be handled through such market mechanisms should be addressed by the government. As such, since firms are not meant to provide a broader benefit to society beyond the product they sell, allocating resources to CSR should be seen as a cost to the firm. Another argument for CSR being simply a cost is the "capability argument" suggesting that firms do not have the right resources to competently deal with societal issues, and may even make a bad situation worse (Whittaker, 2011). Taken together, these two lines of argument suggest that if firms involve themselves in CSR it is to be viewed as a mere cost.

We, on the other hand, argue that CSR initiatives might enhance the effects of advertising spending on firm performance for two reasons. First, individuals have a strong preference for congruent information. Information diagnosticity is higher when information from two or more sources is congruent (Josiassen et al., 2008). As such, consumers who have information about a company through its advertising will find this information more believable or diagnostic if his or her knowledge about the company's CSR efforts is congruent with the advertising message. In other words, we argue that the congruency effect is higher for advertising campaigns that are congruent with the firm's CSR initiatives.

Second, people prefer cognitive consistency. If a consumer or an investor feels positive about the firms' CSR initiatives, such positive feelings are likely to spillover to the firm's advertising. Inconsistency among an individual's thoughts, feelings, and actions create discomfort. Cognitive dissonance theory (Festinger, 1957), a core theory in psychology, posits that such discomfort will be remedied by changing thoughts, feelings, or actions so that they are consistent. CSR initiatives can increase the firm's public goodwill (Houston and Johnson, 2000), and its reputation (Luo 
and Bhattacharya, 2006). In order to avoid cognitive dissonance, consumers and investors (Chang et al., 2016) are likely to align their attitudes towards the firm's advertising due to its CSR initiatives. In other words, the positive reputation created by CSR activities, helps to maximize the effectiveness of advertising on sales and firm value due to more favorable attitudes toward the firm. This effectiveness will directly influence sales, and in turn, the value of the firm (Roberts and Dowling 2002, p1079). We thus put forth the following hypotheses:

H1a: CSR initiatives will positively moderate the effect of advertising spending on sales.

H1b: CSR initiatives will positively moderate the effect of advertising spending on firm value.

\section{Methodology}

\section{Sample and Data}

For the restaurant sample, we have a total of 232 observations covering an unbalanced sample of 22 publicly traded restaurants ${ }^{1}$ from 2001 to $2012^{2}$. We have 82 observations for the hotel sample, covering an unbalanced panel of 9 publicly traded hotels from 2001 to 2012.

For both samples we used the COMPUSTAT database to collect advertising spending and performance data. Following previous research (Luo and De Jong, 2012), we measured advertising spending as the reported firm advertising expenditure in the COMPUSTAT database. For CSR data, we used the KLD Research and Analytics' KLD STAT, one of the most frequently used databases in the strategy and management literature (Hilman and Keim, 2001; McWilliams and Siegel, 2001; Waddock and Graves, 1997). The KLD dataset provides information on CSR activities for publicly traded U.S. firms, either the S\&P 500 or the Russell 3000 indices, and covers over 3000 U.S firms. It covers seven major types of CSR initiatives, including community, corporate governance, diversity, employee relations, environment, human rights, and products (www.wharton.upenn.edu/wrds/ds/kld/). For each firm, over 250 objective indicators are used to indicate to what extent the firm participates in socially responsible actions and builds relation-

1 We focus here on publicly traded firms as we have firm value as one of our performance measures

2 The financial data was not available in some years for all the restaurants included in the sample. Hence, this results in the unbalanced sample. 
ships with various stakeholders (Luo et al., 2015). We measure CSR as total CSR strengths minus total CSR concerns in line with Rekker et al. (2014).

\section{Performance Variables}

We used two performance variables, namely sales and firm value. We measure sales as the reported annual sales in the COMPUSTAT database. For firm value we use the Market Value Added (MVA), calculated as:

MVA $=$ market value-capital

where market value reflects the equity market valuation of the firm and capital reflects the debt and equity invested in the firm. Hence, MVA is "simply the difference between the cash that both debt and equity investors have contributed to a company and the value of the cash that they expect to get out of it. Essentially, MVA is the stock market's estimation of net present value" (Hillman and Keim, 2001, p128). While different measures of firm value have been used in the literature, MVA has better ability to account for future value of income streams (Rappaport, 1991; Lubatkin and Shrieves, 1986). Moreover, MVA captures the debt and equity invested in the firm, and unlike other measures of firm value (e.g. NPV and Tobin's Q) is not very sensitive to accounting problems regarding the anticipation of future cash flows and discount rates (Hayes and Aberathy, 2007; Watts and Zimmerman, 1990; McGuire et al., 1988; McGuire, Schneeweis, and Hill, 1986; Fisher and McGowan, 1983; Bentson, 1982; Ouchi, 1980; Briloff, 1972, 1976; Livingstone and Salamon, 1970). For instance with Tobin's $Q$ (the ratio of a firm's market value to a firm's asset replacement costs), "the valuation of asset replacement costs suffers from the same issues identified with many accounting measures of performance-difficulty in valuing intangible asset" (Hillman and Keim, 2001, p130).

\section{Control variables}

We also included two control variables: Firm size and financial leverage. Both of these variables have been frequently used in prior studies. For instance, firm size is linked to firm performance (Assaf et al. 2016; Assaf and Cvelbar, 2015; Canbäck, Samouel, and Price, 2006; Gelles and Mitchell, 1996). Similarly, several studies (Lee, Seo, and Sharma, 2013; Luo, Homburg, and 
Wieseke, 2010) suggest that financial leverage is a fundamental factor influencing firm value. We measure firm size as the natural log of total assets and financial leverage as firms' long-term book debt over total assets. Table 1 provides descriptive statistics by sample for all variables included in the estimation.

\section{Model Specification and Results}

For each of the two samples, we estimate two separate regressions, one for sales and the other for firm value. Both equations share the same independent variables: advertising, CSR, the interaction of advertising and CSR, firm size and financial leverage. We estimate all equations in a panel regression framework, using STATA.

One of the first steps of panel data estimation is to decide whether to use a random effect or a fixed effect framework. Using the Hausman test, we confirmed that the random effect is more appropriate for our data. For example, for the restaurant sample, the p-value of the Hausman test was 0.6819 for the sales model and 0.2482 for the firm value model. One challenge we faced, however, was that neither the random effect nor the fixed effect converged well with the hotel sample- possibly due to the small number of observations. Hence, we decided to combine both the restaurant and hotel samples in the second dataset. In other words, we provide evidence from two samples, one that represents the restaurant industry alone and one that represents both the restaurant and hotel industries.

The Hausman test for the combined sample again provided support for the random effect estimation for both the sale and firm value models ( $\mathrm{p}$ values $=0.2947$ and 0.0851 , respectively). In Tables 2 and 3 we provide the parameters estimates, along with their associated $z$ values for both the restaurant and combined sample, respectively. The first part of the table presents the impact on firm sales while the second part presents the impact on firm value. Looking at the restaurant sample (Table 2), it is evident that advertising has a significant and positive impact on both restaurant sales and firm value. Table 3 (combined sample) also shows similar results as the impact of advertising is positive and significant on both sales and firm value.

In $\mathrm{H} 1 \mathrm{a}$ and $\mathrm{H} 1 \mathrm{~b}$ we hypothesized that CSR moderates the relationship between advertising and sales and advertising firm value, respectively. The results reported in Table 2 show that the inter- 
action between CSR and advertising has a positive and significant impact on both sales and firm value in the restaurant sample. The results from the combined sample (Table 3) also show that the interaction is positive and significant for both the "sales "and "firm value" models. Taken together, these results are congruent with $\mathrm{H} 1 \mathrm{a}$ and $\mathrm{H} 1 \mathrm{~b}$.

\section{Discussion and Implications}

Why do advertising initiatives lead to profits for some firms and losses for others, and what is the role of corporate social responsibility on the effectiveness of advertising? The findings in this study provide insight to these fundamental questions and addresses Park and Jang's (2014) call for future research on the marketing-finance interface. Previous hospitality research has examined the impact of CSR on firm performance from different angles including CSR awareness (Rhou et al., 2016), appropriateness of CSR activates (Kang et al. 2010) and firm risk (Kim et al. 2016). We extend the literature by arguing that CSR is an important contingency variable explaining why the effect of advertising on sales and firm value varies substantially among firms, Unlike the economic argument viewing CSR initiatives as pure costs (e.g., Whittaker, 2011), we suggest that CSR activities can give a boost to advertising spending due to enhanced reputation. Accordingly, we found that firms with higher levels of CSR enjoy a higher return on advertising spending than their counterparts firms with lower levels of CSR. Based on two datasets, our results show that CSR plays a significant role in the relationship between advertising spending and firm performance. Our findings have important implications for the hospitality industry as researchers and practitioners alike call for a focus on marketing accountability (Rust et al., 2004; Joshi and Hanssens, 2009; Kim and Morris, 2003; Reekie and Bhoyrub, 1981). This study extends research on uncovering contingencies under which advertising works or not, and it contributes to literature examining the effect of CSR on firm performance (e.g., Berens, Riel, and Bruggen, 2005; Luo and Donthu, 2006; Luo and Bhattacharya, 2006). Based on our findings, it is critical for hospitality firms to continuously monitor consumers' and investors' CSR perceptions. If CSR perceptions fade, then spending more on advertising is unlikely to be the answer. Rather, it might be wiser to spend money on CSR initiatives to get to the level where advertising helps firm performance.

The present study is subject to several limitations. The study conclusions are limited to US firms 
given our sample. It would be interesting to validate our findings in less developed economies. Further, the study focused on larger firms, and we thus urge researchers to investigate our assertions in samples which include smaller firms. For future research it would also be of value to investigate whether a threshold can be found below which advertising spending destroys value and above which advertising spending creates value. Identifying such a threshold would have immediate practical and operational implications for hospitality firms. Further, it is likely that the interacting effect of CSR on the efficiency of advertising depends on the aim of the advertising campaign. For example, if the aim is to raise CSR perceptions amongst the target audience, then perhaps advertising could help achieve this goal. However, if the goal is different (like improving quality perceptions) then a low level of CSR might be a hindrance. Thus, it would be interesting to investigate whether the goal of the advertising campaign plays a role in determining how CSR influences its effectiveness. 
Table 1. Descriptive Statistics

\begin{tabular}{|c|c|c|}
\hline \multicolumn{3}{|c|}{ Restaurant Sample } \\
\hline Variable & Mean & SD \\
\hline Sales & 3246.68 & 5183.20 \\
\hline MVA & 2980.09 & 8864.25 \\
\hline Advertising & 106.65 & 186.79 \\
\hline CSR & 1.36 & 6.21 \\
\hline Firm Size & 3.00 & 0.56 \\
\hline Financial Leverage & 0.64 & 0.61 \\
\hline & Combined Sample & \\
\hline Variable & Mean & SD \\
\hline Sales & 2996.35 & 4656.50 \\
\hline MVA & 1877.33 & 8244.15 \\
\hline Advertising & 92.58 & 163.88 \\
\hline CSR & 0.80 & 5.88 \\
\hline Firm Size & 3.08 & 0.61 \\
\hline Financial Leverage & 0.67 & 0.55 \\
\hline
\end{tabular}


Table 2. Random-Effect Regression Estimates- Restaurant Sample

\begin{tabular}{|c|c|c|c|}
\hline \multicolumn{5}{|c|}{ Dependent Variable: Sales } \\
\hline Variable & Coeff & Z-value & p-value \\
\hline Advertising & $20.38^{* *}$ & 14.40 & 0.000 \\
\hline CSR & $50.35^{* *}$ & 2.27 & 0.023 \\
\hline Advertising*CSR & $0.25^{* *}$ & 3.93 & 0.000 \\
\hline Firm Size & $1.554 \mathrm{E}+3^{* *}$ & 3.97 & 0.000 \\
\hline Financial Leverage & 72.64 & 0.35 & 0.726 \\
\hline & Dependent Variable: Firm Value & p-value \\
\hline Variable & Coeff & Z-value & 0.000 \\
\hline Advertising & $23.40^{* *}$ & 3.92 & 0.267 \\
\hline CSR & -123.63 & -1.11 & 0.000 \\
\hline Financial Leverage & -305.61 & 6.27 & 0.974 \\
\hline Firm Size & $2.06^{* *}$ & -0.03 & 0.34 \\
\hline$*$ Significantat & -59.63 & & \\
\hline & & & \\
\hline
\end{tabular}

** Significant at the $5 \%$ confidence level or better 
Table 3. Random-Effect Regression Estimates- Combined Sample

\begin{tabular}{|c|c|c|c|}
\hline \multicolumn{4}{|c|}{ Dependent Variable: Sales } \\
\hline Variable & Coeff & Z-value & $\mathrm{p}$-value \\
\hline Advertising & $19.75^{* *}$ & 16.80 & 0.000 \\
\hline CSR & 16.64 & 1.02 & 0.306 \\
\hline Advertising*CSR & $0.30 * *$ & 5.61 & 0.000 \\
\hline Firm Size & $1.96 \mathrm{E}+3^{* *}$ & 7.10 & 0.000 \\
\hline Financial Leverage & 126.49 & 0.67 & 0.500 \\
\hline \multicolumn{4}{|c|}{ Dependent Variable: Firm Value } \\
\hline Variable & Coeff & Z-value & $\mathrm{p}$-value \\
\hline Advertising & $28.05^{* *}$ & 5.84 & 0.000 \\
\hline CSR & $-166.56^{* *}$ & -1.99 & 0.046 \\
\hline Advertising*CSR & $2.17 * *$ & 7.61 & 0.000 \\
\hline Firm Size & $-2.53 \mathrm{E}+3 * *$ & -2.16 & 0.031 \\
\hline Financial Leverage & -370.46 & -0.44 & 0.659 \\
\hline
\end{tabular}

** Significant at the $5 \%$ confidence level or better 


\section{References}

Aaker, D. A., 1996. Measuring brand equity across products and markets. California management review, 38(3), 103.

Abdel-Khalik, A.R., 1975. Advertising effectiveness and accounting policy. Accounting Review, 50, 657-669.

Ailawadi, K. L., Lehmann, D. R., \& Neslin, S. A., 2003. Revenue premium as an outcome measure of brand equity. Journal of Marketing, 67(4), 1-17.

Ali Shah, S. Z., \& Akbar, S., 2008. Value relevance of advertising expenditure: a review of the literature. International Journal of Management Reviews, 10(4), 301-325.

Assaf, A. G., Josiassen, A., Oh, H., 2016. Internationalization and Hotel performance: The Missing Pieces, Tourism Economics, 22, 572592.

Assaf, A.G. and Cvelbar, L.K., 2015. Why negative outputs are often ignored: a comprehensive measure of hotel performance. Tourism Economics, 21(4), 761-773.

Assaf, A. G., Josiassen, A., Mattila, A. S., \& Cvelbar, L. K., 2015. Does advertising spending improve sales performance? International Journal of Hospitality Management, 48, 161-166.

Bentson G., 1982. Accounting numbers and economic values. Antitrust Bulletin Spring: 161-215.

Berens, G., Riel, C. B. V., \& Bruggen, G. H. V., 2005. Corporate associations and consumer product responses: The moderating role of corporate brand dominance. Journal of Marketing, 69(3), 35-48.

Boulding, W., Lee, E., \& Staelin, R., 1994. Mastering the mix: Do advertising, promotion, and sales force activities lead to differentiation?. Journal of Marketing Research, 159-172.

Boyd, J. H., \& Schonfeld, E. P., 1977. The effect of financial press advertising on stock prices. Financial Management, 42-51.

Briloff R., 1972. Unaccountable Accounting. Harper Row: New York.

Briloff R., 1976. The Truth about Corporate Accounting. Harper \& Row: New York.

Canback, S., Samouel, P., \& Price, D., 2006. Do diseconomies of scale impact firm size and performance? A theoretical and empirical overview. ICFAI Journal of Managerial Economics, 4(1), 27-70.

Chang, T. Y., Solomon, D. H., \& Westerfield, M. M. , 2016. Looking for someone to blame: Delegation, cognitive dissonance, and the disposition effect. The Journal of Finance, 71(1), 267-302.

Chauvin, K. W., \& Hirschey, M., 1993. Advertising, R\&D expenditures and the market value of 
the firm. Financial management, 128-140.

Chen, C. M., \& Lin, Y. C., 2013. How do advertising expenditures influence hotels' performance?. International Journal of Hospitality Management, 33, 490-493.

Denizci, B., \& Li, X. R, 2009. Linking marketing efforts to financial outcome: An exploratory study in tourism and hospitality contexts. Journal of Hospitality \& Tourism Research, 33(2), 211-226.

Eichholtz, P., Kok, N., \& Quigley, J. M., 2010. Doing well by doing good? Green office buildings. The American Economic Review, 100(5), 2492-2509.

Erickson, G., \& Jacobson, R., 1992. Gaining comparative advantage through discretionary expenditures: The returns to R\&D and advertising. Management science, 38(9), 1264-1279.

Farquhar, P., 1989. Managing brand equity. Marketing Research (September), 24-33.

Festinger, L., 1957. Cognitive dissonance theory. 1989) Primary Prevention of HIV/AIDS: Psychological Approaches. Newbury Park, California, Sage Publications.

Fisher, F. M., \& McGowan, J. J., 1983. On the misuse of accounting rates of return to infer monopoly profits. The American Economic Review, 73(1), 82-97.

Frieder, L., \& Subrahmanyam, A., 2005. Brand perceptions and the market for common stock. Journal of financial and Quantitative Analysis, 40(01), 57-85.

Friedman, M., 2013. Why government is the problem. Hoover Press.

Gelles, G. M., \& Mitchell, D. W., 1996. Returns to scale and economies of scale: Further observations. The Journal of Economic Education, 27(3), 259-261.

Han, B. H., \& Manry, D., 2004. The value-relevance of R\&D and advertising expenditures: evidence from Korea. The International Journal of Accounting, 39(2), 155-173.

Hayes, R. H., \& Abernathy, W. J., 2007. Managing our way to economic decline. Harvard Business Review, 85(7-8).

Heath, C., \& Tversky, A., 1991. Preference and belief: Ambiguity and competence in choice under uncertainty. Journal of risk and uncertainty, 4(1), 5-28.

Hillman, A. J., \& Keim, G. D., 2001. Shareholder value, stakeholder management, and social issues: what's the bottom line?. Strategic Management Journal, 22(2), 125-139.

Ho, Y. K., Keh, H. T., \& Ong, J. M., 2005. The effects of R\&D and advertising on firm value: an examination of manufacturing and nonmanufacturing firms. Engineering Management, IEEE Transactions on, 52(1), 3-14.

Houston, M. B., \& Johnson, S. A., 2000. Buyer-supplier contracts versus joint ventures: Determinants and consequences of transaction structure. Journal of Marketing Research, 37(1), 
$1-15$.

Hsu, L. T. J., \& Jang, S. S., 2008. Advertising expenditure, intangible value and risk: A study of restaurant companies. International Journal of Hospitality Management, 27(2), 259-267.

Joshi, A. M., \& Hanssens, D. M., 2009. Movie advertising and the stock market valuation of studios: a case of "great expectations?. Marketing Science, 28(2), 239-250.

Joshi, A., \& Hanssens, D. M., 2010. The direct and indirect effects of advertising spending on firm value. Journal of Marketing, 74(1), 20-33.

Josiassen, A., Lukas, B. A., \& Whitwell, G. J., 2008. Country-of-origin contingencies: Competing perspectives on product familiarity and product involvement. International Marketing Review, 25(4), 423-440.

Kang, K. H., Lee, S., \& Huh, C., 2010. Impacts of positive and negative corporate social responsibility activities on company performance in the hospitality industry. International Journal of Hospitality Management, 29(1), 72-82.

Keller, Kevin Lane., 1998. Strategic Brand Management. New York: McGraw-Hill.

Kim, M., \& Kim, Y., 2014. Corporate social responsibility and shareholder value of restaurant firms. International Journal of Hospitality Management, 40, 120-129.

Kim, Y., Kim, M., \& Mattila, A. S., 2016. Corporate Social Responsibility and Equity-Holder Risk in the Hospitality Industry. Cornell Hospitality Quarterly, 1938965516649052.

Kim, J., \& Morris, J. D., 2003. The effect of advertising on the market value of firms: Empirical evidence from the super bowl ads. Journal of Targeting, Measurement and Analysis for Marketing, 12(1), 53-65.

Kirmani, A., \& Zeithaml, V., 1993. Advertising, perceived quality, and brand image (pp. 143-62). Hillsdale, NJ: Lawrence Erlbaum Associates.

Lee, S., \& Park, S. Y., 2009. Do socially responsible activities help hotels and casinos achieve their financial goals? International Journal of Hospitality Management, 28(1), 105-112.

Lee, S., Seo, K., \& Sharma, A., 2013. Corporate social responsibility and firm performance in the airline industry: The moderating role of oil prices. Tourism Management, 38, 20-30.

Leon, C. J., \& Araña, J. E. (2014). Impact of different dimensions of corporate social responsibility on tourism demand: does the status quo matter? Tourism Economics, 20(3), 493-507.

Livingstone, J. L., \& Salamon, G. L., 1970. Relationship between the accounting and the internal rate of return measures: A synthesis and an analysis. Journal of Accounting Research, 8(2), 199-216.

Lubatkin, M., \& Shrieves, R. E., 1986. Towards reconciliation of market performance measures 
to strategic management research. Academy of Management Review, 11(3), 497-512.

Luo, X., \& Bhattacharya, C. B., 2006. Corporate social responsibility, customer satisfaction, and market value. Journal of Marketing, 70(4), 1-18.

Luo, X., \& de Jong, P. J., 2012. Does advertising spending really work? The intermediate role of analysts in the impact of advertising on firm value. Journal of the Academy of Marketing Science, 40(4), 605-624.

Luo, X., \& Donthu, N., 2006. Marketing's credibility: A longitudinal investigation of marketing communication productivity and shareholder value. Journal of Marketing, 70(4), 70-91.

Luo, X., \& Du, S., 2015. Exploring the relationship between corporate social responsibility and firm innovation. Marketing Letters, 26(4), 703-714.

Luo, X., Homburg, C., \& Wieseke, J., 2010. Customer satisfaction, analyst stock recommendations, and firm value. Journal of Marketing Research, 47(6), 1041-1058.

Luo, X., Wang, H., Raithel, S., \& Zheng, Q., 2015. Corporate social performance, analyst stock recommendations, and firm future returns. Strategic Management Journal, 36(1), 123-136.

McGuire, Jean B., Alison Sundgren., \& Thomas Schneeweis., 1988. Corporate Social Responsibility and Firm Financial Performance. Academy of Management Journal 31:854-72

McGuire, J., Schneeweis, T., \& Hill, J., 1986. An analysis of alternative measures of strategic performance. Advances in strategic management, 4(2), 1986.

McWilliams, A., \& Siegel, D., 2001. Corporate social responsibility: A theory of the firm perspective. Academy of management review, 26(1), 117-127.

Mela, C. F., Gupta, S., \& Lehmann, D. R., 1997. The long-term impact of promotion and advertising on consumer brand choice. Journal of Marketing Research, 248-261.

Mitrokostas, E., \& Apostolakis, A. (2013). Research note: Strategic corporate social responsibility and competition in the tourism industry-a theoretical approach. Tourism Economics, 19(4), 967-975.

Mizik, N., \& Jacobson, R., 2003. Trading off between value creation and value appropriation: The financial implications of shifts in strategic emphasis. Journal of Marketing, 67(1), 63-76.

O’Neill, J.W., Hanson, B., Mattila, A.S., 2008. The relationship of sales and marketing

expenses to hotel performance in the United States. Cornell Hosp. Q. 49 (4),

$355-363$.

Ouchi, W. G., 1980. Markets, bureaucracies, and clans. Administrative science quarterly, 129-141.

Park, K., \& Jang, S., 2014. Hospitality finance and managerial accounting research: Suggesting an interdisciplinary research agenda. International Journal of Contemporary Hospitality Man- 
agement, 26(5), 751-777.

Park, S. Y., \& Lee, S., 2009. Financial rewards for social responsibility a mixed picture for restaurant companies. Cornell Hospitality Quarterly, 50(2), 168-179.

Pauwels, K., Silva-Risso, J., Srinivasan, S., \& Hanssens, D. M., 2004. New products, sales promotions, and firm value: The case of the automobile industry. Journal of Marketing, 68(4), 142-156.

Peles, Y., 1970. Amortization of advertising expenditures in the financial statements. Journal of Accounting Research, 8, 128-137

Price Waterhouse Cooper, 2012. Do investors care about sustainability, Retrieved from http://www.pwc.com/us/en/corporate-sustainability-climatechange/publications/investors-and-sustainability.html

Rappaport, A., 1991. CFOs and strategists: forging a common framework. Harvard Business Review, 70(3), 84-91.

Reekie, W. D., \& Bhoyrub, P., 1981. Profitability and intangible assets: another look at advertising and entry barriers. Applied Economics, 13(1), 99-107.

Rekker, S. A., Benson, K. L., \& Faff, R. W. (2014). Corporate social responsibility and CEO compensation revisited: Do disaggregation, market stress, gender matter? Journal of Economics and Business, 72, 84-103.

Rhou, Y., Singal, M., \& Koh, Y., 2016. CSR and financial performance: The role of CSR awareness in the restaurant industry. International Journal of Hospitality Management, 57, 30-39.

Roberts, P. W., \& Dowling, G. R., 2002. Corporate reputation and sustained superior financial performance. Strategic Management Journal, 23(12), 1077-1093.

Rust, R. T., Ambler, T., Carpenter, G. S., Kumar, V., \& Srivastava, R. K., 2004. Measuring marketing productivity: Current knowledge and future directions. Journal of Marketing, 68(4), 7689.

Schwartz, A., 2015. 3 ways brands can use corporate social responsibility principles to create better marketing, Retrieved from http://www.fastcoexist.com/3044195/3-ways-brands-canuse-corporate-social-responsibility-principles-to-create-better-advertisin.

Waddock, S. A., \& Graves, S. B., 1997. The corporate social performance-financial performance link. Strategic Management Journal, 18(4), 303-319.

Watts, R. L., \& Zimmerman, J. L., 1990. Positive accounting theory: a ten year perspective. Accounting review, 131-156. 
Whittaker, J, 2011. The evolution of environmentally responsible investment: An Adam Smith perspective. Ecological Economics, 71, 33-41.

Vanhamme, J., Lindgreen, A., Reast, J., \& van Popering, N., 2012. To do well by doing good: Improving corporate image through cause-related marketing. Journal of Business Ethics, 109(3), 259-274. 